\title{
不安定な補償器を用いた低剛性・高慣性比の二慣性系に おける外乱抑制性能の改善*
}

高山＼cjkstart誠 • 小林 泰秀 $\dagger$

\author{
An Improvement by Unstable Controller in Disturbance \\ Suppression Performance of Two-inertia System \\ with Low Stiffness and High Inertia Ratio*
}

Makoto TAKAYAMA $^{\dagger}$ and Yasuhide KoBAYASHI ${ }^{\dagger}$

\begin{abstract}
In order to improve control performance given by stable controller for disturbance suppression problem of two-inertia system with low stiffness and high inertia ratio, this paper proposes a simple structure of controller which has a similar characteristic of unstable controller given by $\mathcal{H}_{\infty}$ control design. The proposed controller has two tunable parameters, and a tuning procedure to minimize the closed-loop gain with desired stable margins is given, by which the proposed controller can be easily adjusted when physical parameters are changed. The optimal closed-loop gain by conventional control method (proportional control) and an rate of improvement by proposed method are theoretically given in terms of physical parameters of plant. The validity of the proposed method is shown by experimental results.
\end{abstract}

\section{1.はじめに}

近年，さまざまな制御対象に対して，できるだけ簡便 な方法で良い制御性能を達成しようとする沉用サーボ モータが産業用機械の駆動装置として広く用いられてい る.このようなモータの中には, 慣性や摩擦の推定機構 を組み合わせ，推定された物理パラメータから，ノッチ の周波数や補償器のゲインを自動調整し，ユーザの調整 がほとんど必要のないオートチューニングやチューニン グレスの機能をもつものもある $[1,2]$.

多くの沉用サーボモータでは, 補償器として従来経験 的に広く用いられているノッチフィルタや PID 制御則な どの安定な補償器を採用しているが，現実に接続される 制御対象や求められる仕様はユーザによって幅広く，常 に従来の補償器構造とその調整則によって十分な性能が 得られるとは限らない。実際，低剛性・高慣性比の二慣 性系において十分な制御性能を得ることが難しい欠点を もつ。 また，機械の軽量化・高速化に伴って，低剛性·

\footnotetext{
* 原稿受付 2016 年 11 月 25 日

第 58 回自動制御連合講演会にて発表 (2015 年 11 月)

$\dagger$ 長岡技術科学大学 大学院 工学研究科 Graduate School of Engineering, Nagaoka University of Technology;16031 Kamitomiokamachi, Nagaoka city, Niigata 940-2188, JAPAN
}

Key Words: two-inertia system, disturbance suppression, unstable controller.
高慣性比の二慣性系の制御が必要になり，制御性能の改 善が求められている。すすおち，良い性能を得ようとす るほど, 問題設定に強く依存する補償器構造が必要にな ると考えられる。

いっぽう， $\mathcal{H}_{\infty}$ 制御などのロバスト制御系設計を行え ば，与えられた制御対象の情報に基づき， $\mathcal{H}_{\infty}$ ノルムな どの意味で最適で不安定な補償器を得ることができる. しかし, 得られる補償器の動特性と制御対象の物理パラ メータの関連は，単純な二慣性系の場合でさえ明らかで はないため, 制御対象が変更されるたびに補償器の再設 計を行わなければならず，計算コストが問題となる.

本研究では，典型的な問題設定ごとに，良い性能が達 成でき，かつ，調整が容易な補償器構造を提案すること を目指す。そのために制御対象の物理パラメー夕は既知 または推定可能で, 補償器の設定に利用できることとす る。本論文では低剛性・高慣性比の外乱抑制問題を取り 扱う。 その際，多くの汎用サーボモータで慣性比 10〜30 倍が許容值とされていることから（たとえば [1]），慣性 比 10 倍以上を想定する。これまで二慣性系の制御法と してさまざまな方法が研究されている [3]. しかし，それ らの多くは 10 倍未満の慣性比を想定しており [4-8], 本 研究の問題設定は扱われていない.

従来研究 [9] において, 安定化補償器のパラメトリゼー ションに基づいた, 制御対象の物理パラメータに陽に依 存する不安定な補償器が提案されたが，閉ループ系のゲ 


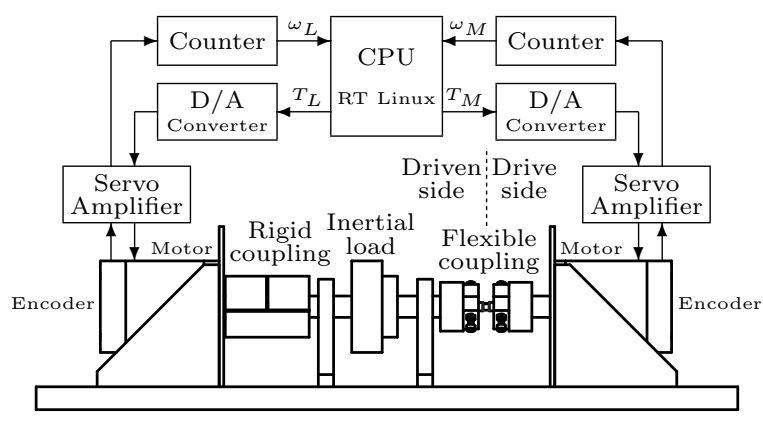

Fig. 1 Block diagram of experimental apparatus

Table 1 Experimental equipments

\begin{tabular}{l|l}
\multicolumn{2}{c}{ Table 1 Experimental equipments } \\
\hline PC & $\begin{array}{l}\text { Dell Dimension 2100 / Fedora Core 1 } \\
\text { (RTLinux 3.2-pre3, Linux kernel 2.4.22) }\end{array}$ \\
\hline D/A & CONTEC DA12-4(PCI) (12bit, 10 $\mu \mathrm{s})$ \\
\hline counter & CONTEC CNT24-4(PCI)H $(24 \mathrm{bit}, 1 \mathrm{MHz})$ \\
\hline PIO & $\begin{array}{l}\text { CONTEC PIO-32/32T(PCI) } \\
\text { (Parallel input output, 32bit 200ns) }\end{array}$ \\
\hline $\begin{array}{l}\text { Driving } \\
\text { motor }\end{array}$ & $\begin{array}{l}\text { YASKAWA ELECTRIC CORP. } \\
\text { SGMAV-02A, SGDV-1R6A } \\
\text { (rated power 200 W, } \\
\text { rated torque 0.637 Nm }(\max 1.91 \mathrm{Nm}), \\
\left.\text { rotor inertia moment 0.116 } \times 10^{-4} \mathrm{~kg} \cdot \mathrm{m}^{2}\right)\end{array}$ \\
\hline $\begin{array}{l}\text { Driven } \\
\text { motor }\end{array}$ & $\begin{array}{l}\text { MITSUBISHI ELECTRIC CORP. } \\
\text { HF-MP23, MR-J3-20A } \\
(\text { rated power 200 W, } \\
\text { rated torque 0.64 Nm }(\max 1.9 \mathrm{Nm}), \\
\left.\text { rotor inertia moment } 0.088 \times 10^{-4} \mathrm{~kg} \cdot \mathrm{m}^{2}\right)\end{array}$ \\
\hline
\end{tabular}

インが 0 となる仮想的補償器をべースとしており，補償 器がハイゲインでパラメータ変動に対する安定余裕が小 さいという実用上の問題があった。

本研究でも従来研究と同様に, 安定な補償器で得られ る制御性能を改善するために，不安定な補償器構造を提 案する。その際，現実的な大きさの不確かさを考慮した $\mathcal{H}_{\infty}$ 補償器をベースとすることにより，所望の安定余裕 を達成し，かつ閉ループ系のゲインを最小化するような 可調整パラメータの設定法を示す。さらに，提案する補 償器の実用性を実験により確認する。

\section{2. 実験装置と問題設定}

本節では，本研究で扱う実験装置と問題設定を述べる。 実験装置の概要を Fig. 1 に，装置諸元を Table 1 に示 す。ほほ同じ仕様の二つの AC サーボモータが，板ばね を用いた柔軟カップリングを介してサーボモータの約 20 倍の慣性負荷ディスクに接続されている。パソコンから $\mathrm{D} / \mathrm{A}$ 変換器を介して二つのサーボモータのトルク指令 $T_{M}, T_{L}$ を与え，ロータリエンコーダとカウンタを用い て各モータの回転速度 $\omega_{M} ， \omega_{L}$ を計測できる。 Fig. 1 の閉ループ系を Fig. 2 のように表す。システムの制御目 的は従動側慣性に働く外乱トルク $T_{L}$ に対して，駆動側 モータで適当なトルク $T_{M}$ を与えることによって, 従動 側慣性の速度 $\omega_{L}$ を一定に保つことである， $T_{M}$ は駆動 側モー夕の速度 $\omega_{M}$ を計測することによって生成され る。すなわち， $\omega_{M}$ と $T_{M}$ はそれぞれ設計される補償器

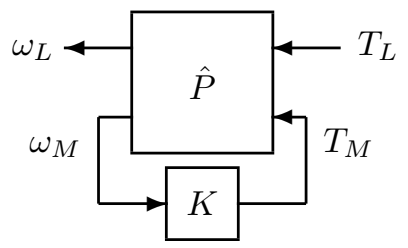

Fig. 2 Closed-loop system

$K$ の入力と出力である

$\left[\begin{array}{ll}T_{L} & T_{M}\end{array}\right]^{\mathrm{T}}$ から $\left[\begin{array}{ll}\omega_{L} & \omega_{M}\end{array}\right]^{\mathrm{T}}$ までの入出力関係を $\hat{P}(s)$ と表す. ここで, $\hat{P}_{a b}(s)$ を $b$ から $a$ までの伝達関 数とし， $a=1 ， 2$ がそれぞれ $\omega_{L}, \omega_{M}$ に, $b=1,2$ が それぞれ $T_{L}, T_{M}$ に対応するとして次式のように表す.

$$
\hat{P}(s):=\left[\begin{array}{ll}
\hat{P}_{11}(s) & \hat{P}_{12}(s) \\
\hat{P}_{21}(s) & \hat{P}_{22}(s)
\end{array}\right]
$$

次の外乱抑制問題を考える。以下の条件を満足し，か つ, $\gamma$ を最小化する補償器 $K(s)$ を求める問題である.

(1) Fig. 2 の閉ループ系が内部安定

(2) 所望の安定余裕を確保

(3) $\left\|G_{\mathrm{cl}}\right\|_{\infty}<\gamma$

ただし， $G_{\mathrm{cl}}$ は $T_{L}$ から $\omega_{L}$ までの閉ループ伝達関数で ある。

上記の問題では従動側の慣性負荷における外乱抑制性 能のみが評価されており, 駆動側モー夕に関する制約は 課されていない. よって, 負荷の振動を抑制するために, 駆動側モータが激しく振動するような状況が許される問 題設定となっていることに注意されたい。この結果次節 で，駆動側慣性に許された振動と引き換えに従動側慣性 の振動を抑制する積極的な制御則が不安定な補償器とし て得られていると考えられる。二慣性ねじり振動系に対 して $\mathcal{H}_{\infty}$ 制御系設計を行った研究は数多く報告されてい るが（たとえば $[10,11] ）$ ，上記の点が従来研究と異なる.

\section{3. 提案する不安定な補償器構造の動機付け}

本節では，実機に対して $\mathcal{H}_{\infty}$ 制御系設計を行った概 要について述べ, 提案する不安定な補償器構造を動機付 ける。 $\mathcal{H}_{\infty}$ 制御系設計では閉ループ系の安定性を保証す るために，ノミナルプラントのモデル化誤差を乗法的摂 動モデルを用いて見積もる。 また，定数スケーリング付 き $\mathcal{H}_{\infty}$ 制御問題に帰着して補償器設計を行う.

\section{$3.1 \mathcal{H}_{\infty}$ 制御系設計}

周波数応答実験を行って, $\hat{P}(s)$ の周波数応答を取得 する． $T_{M}(t) \equiv 0 ， T_{L}(t)$ として正弦波信号を入力し， $\hat{P}_{11}(s)$ と $\hat{P}_{21}(s)$ の周波数応答を, $T_{L}(t) \equiv 0, T_{M}(t)$ として正弦波信号を入力し, $\hat{P}_{12}(s)$ と $\hat{P}_{22}(s)$ の周波数 応答を Fig. 3 の点のように得る。

物理モデルを $\hat{P}(s)$ に対するノミナルプラント

$$
P(s):=\left[\begin{array}{ll}
P_{11}(s) & P_{12}(s) \\
P_{21}(s) & P_{22}(s)
\end{array}\right]
$$




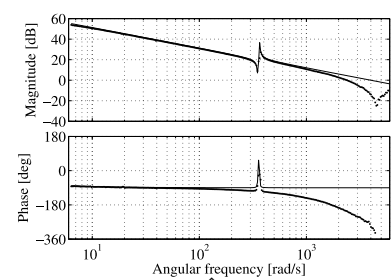

$\hat{P}_{11}$
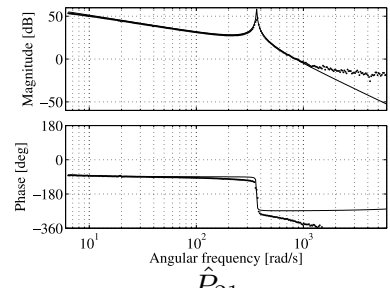

$\hat{P}_{21}$
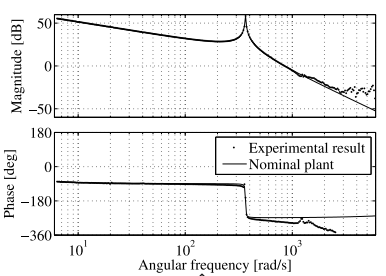

$\hat{P}_{12}$
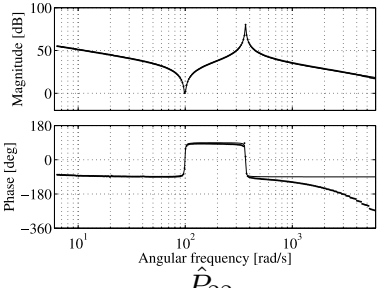

$\hat{P}_{22}$
Fig. 3 Frequency response of plant

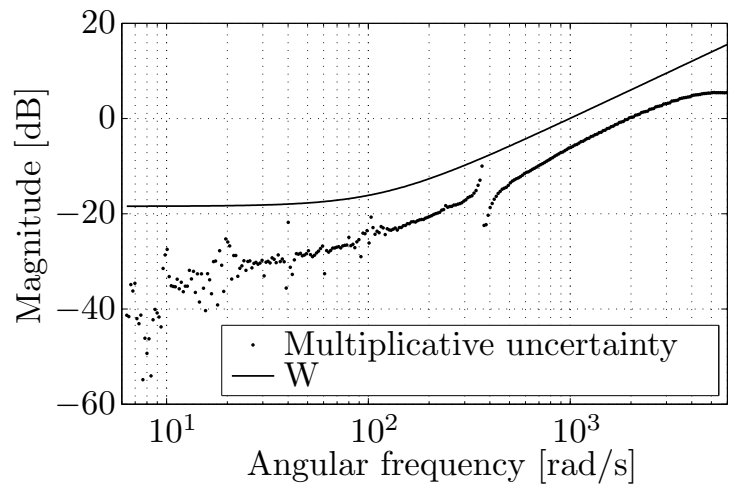

Fig. 4 Weight function

として，補償器設計を行う。物理モデルの詳細について は 4.で述べる。その際, $P_{22}(s)$ のモデル化誤差を次の ような乗法的摂動モデルを用いて見積もる.

$$
\hat{P}_{22}(s)=P_{22}(s)(1+W(s) \delta(s))
$$

ここで， $W(s)$ は安定な重み関数で， $\delta(s) \in R H_{\infty}$ は正 規化されたモデル化誤差である．Fig. 4 にモデル化誤差 $\frac{\hat{P}_{22}(s)-P_{22}(s)}{P_{22}(s)}$ および重み関数 $W(s)$ のゲイン特性を 示す。ただし， $W(s)$ はモデル化誤差を覆うように次式 のように決定した。

$$
W(s)=0.001(s+120)
$$

この $W(s)$ はインプロパであるが, $W(s) P_{22}(s)$ がプロ パとなるため補償器設計が行える.

Fig. 5 に示す定数スケーリング付き $\mathcal{H}_{\infty}$ 制御問題を 解いて, $\mathcal{H}_{\infty}$ 補償器を求める。 すなわち, 以下の条件下 で, 正数 $\gamma$ を最小化する $K(s)$ を求める問題である.

(1) Fig. 5の閉ループ系が内部安定

(2) 適当な定数スケーリング $d>0$ が存在し，閉ルー プ系の $\mathcal{H}_{\infty}$ ノルムが 1 未満

以上に基づき $\mathcal{H}_{\infty}$ 補償器設計を行った結果得られた $\mathcal{H}_{\infty}$ 補償器のボード線図を Fig. 6 の細い実線に示す。共

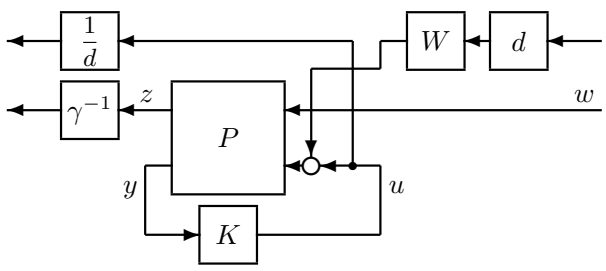

Fig. 5 Robust performance problem with scaling

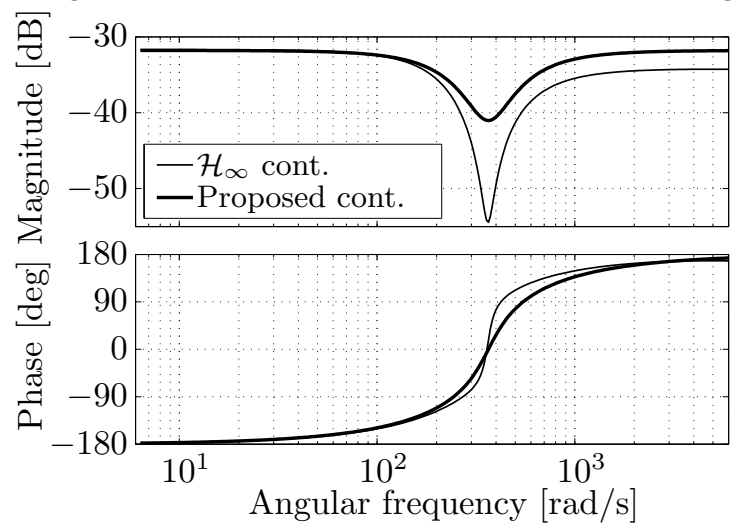

Fig. 6 Bode diagram of controllers

振角周波数 $351 \mathrm{rad} / \mathrm{s}$ 付近でノッチ特性をもつことがわ かる。ただし，位相が $360^{\circ}$ 進んでおり，従来用いられ るノッチフィルタとは異なり, 不安定な補償器となって いる. $\mathcal{H}_{\infty}$ 制御系設計では，積極的に性能を最適化した 際に，しばしば不安定な補償器が得られることがある。 本節の問題ではロバスト安定余裕をさらに小さくして性 能向上を図る場合にも常に得られることを確認している. このような不安定な補償器は, 従来の PID 制御やノッチ フィルタでは表現することができない.

ノッチ中心の角周波数はほぼ制御対象の共振角周波数 に一致しており，開ループ系 $\hat{P}_{22} K$ のゲイン特性がピー クをもたないように， $\hat{P}_{22}$ の共振ピークをつぶしている と考えられる。位相特性が進んでいる直感的な理由は明 らかではないが, この結果, 開ループ系のナイキスト軌 跡は共振角周波数付近で, 補償器 $K$ のノッチで低減さ れた $\hat{P}_{22}$ のゲイン特性で定まる余裕をもって，点 -1 を 囲むようになる。

\section{2 提案型補償器の導入}

本論文では,

$$
K_{\text {prop }}(s)=-a_{0} \frac{s^{2}+2 a_{1} \omega_{n} s+\omega_{n}^{2}}{s^{2}+2 \zeta \omega_{n} s+\omega_{n}^{2}}, \quad \zeta=-\frac{1}{\sqrt{2}}
$$

を, $\mathcal{H}_{\infty}$ 補償器に似た特性をもつ簡便な補償器構造と して提案する。この提案型補償器のボード線図を Fig. 6 の太い実線に示す。 $\omega_{n}$ は 4. で述べる非減衰共振角周波 数である。ここで， $\zeta<0$ より，この補償器は不安定で ある. また，分子多項式の形より，共振角周波数付近で ノッチ特性をもつ。ただし，分母多項式の虚軸上におけ る絶対值が低角周波数域でできるだけフラットな特性を 示すように（ノッチ特性ができるだけ分子多項式の特性 
で定まるように）， $\zeta=-\frac{1}{\sqrt{2}}$ としている。

$a_{0}$ と $a_{1}$ は制御対象に依存して決定されるべき正数の 可調整パラメータである。本論文の以降の目的は，この 可調整パラメータの最適值を制御対象の物理パラメータ を用いて表すことである.

\section{4. 物理モデル}

本節では，実験装置の物理モデルについて述べた後， 正規化した物理モデルを与える。本論文では以下，3.で 述べた外乱抑制問題の意味で最適な，提案型補償器の可 調整パラメー夕の決定法を与える。その際の議論が容易 となるように本節では，括もに慣性比に関して適当な正 規化を施すことにより，一般性を失うことなくパラメー 夕の数を減らした簡単な物理モデルの表現を導出して おく.

\section{1 実験装置の物理モデル}

Fig. 7 のような二慣性系を考える. 二慣性系の運動方 程式は次式で与えられる。

$$
\begin{aligned}
J_{M} \dot{\omega}_{M} & =T_{M}-T_{S} \\
T_{S} & =K_{S} \theta_{r}+C_{S} \dot{\theta}_{r}, \quad \dot{\theta}_{r}=\omega_{M}-\omega_{L} \\
J_{L} \dot{\omega}_{L} & =T_{L}+T_{S}-C_{L} \omega_{L}
\end{aligned}
$$

ただし， $T_{S}$ は軸のねじりトルク， $\theta_{r}$ は両慣性の相対角 度（軸のねじれ角）， $J_{M}$ は駆動側慣性モーメント， $J_{L}$ は従動側慣性モーメント, $K_{S}$ は軸のねじりバネ定数, $C_{S}$ は軸の減衰係数, $C_{L}$ は従動側の減衰係数である.

システム $P$ の状態を $x:=\left[\begin{array}{lll}\theta_{r} & \omega_{M} & \omega_{L}\end{array}\right]^{\mathrm{T}}$, 入力を $u:=\left[\begin{array}{ll}T_{L} & T_{M}\end{array}\right]^{\mathrm{T}}$, 出力を $y:=\left[\begin{array}{ll}\omega_{L} & \omega_{M}\end{array}\right]^{\mathrm{T}}$ とおくと, この状態空間表現は次のように与えられる.

$$
\begin{aligned}
& \dot{x}=A x+B u, \quad y=C x \\
& {\left[\begin{array}{c}
A_{i}^{\prime} B \\
\hdashline C^{\top} 0
\end{array}\right]=\left[\begin{array}{cc:ccc}
0 & 1 & -1 & 0 & 0 \\
-\frac{K_{S}}{J_{M}} & -\frac{C_{S}}{J_{M}} & \frac{C_{S}}{J_{M}} & 0 & \frac{1}{J_{M}} \\
\frac{K_{S}}{J_{L}} & \frac{C_{S}+C_{L}}{J_{L}} & -\frac{C_{S}}{\underline{J}_{L_{L}}} & \frac{1}{J_{L}} & 0 \\
\hdashline 0 & 0 & 1 & 0 & 0 \\
0 & 1 & 0 & 0 & 0
\end{array}\right]}
\end{aligned}
$$

また，システムの伝達関数行列は次式で与えられる $[9]$.

$$
\begin{gathered}
P(s):=\left[\begin{array}{ll}
P_{11}(s) & P_{12}(s) \\
P_{21}(s) & P_{22}(s)
\end{array}\right] \\
=\frac{\left[\begin{array}{cc}
J_{M} s^{2}+C_{S} s+K_{S} & C_{S} s+K_{S} \\
C_{S} s+K_{S} & J_{L} s^{2}+\left(C_{S}+C_{L}\right) s+K_{S}
\end{array}\right]}{s J\left(\bar{J} s^{2}+C_{S} s+K_{S}\right)+C_{L}\left(J_{M} s^{2}+C_{S} s+K_{S}\right)}, \\
J:=J_{M}+J_{L}, \quad \bar{J}:=\frac{J_{M} J_{L}}{J_{M}+J_{L}}
\end{gathered}
$$

ここで, $P_{22}(s)$ の非減衰共振角周波数 $\omega_{n}$ と非減衰反共 振角周波数 $\omega_{a}$, すなわち $C_{L}=C_{S}=0$ としたときの共

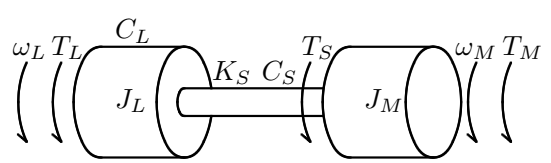

Fig. 7 Two-inertia system

Table 2 Physical parameter

\begin{tabular}{l|l||l|l}
\hline$J_{M}$ & $2.00 \times 10^{-5} \mathrm{~kg} \cdot \mathrm{m}^{2}$ & $C_{S}$ & $8.0 \times 10^{-5} \mathrm{~N} \cdot \mathrm{m} \cdot \mathrm{s} / \mathrm{rad}$ \\
\hline$J_{L}$ & $2.51 \times 10^{-4} \mathrm{~kg} \cdot \mathrm{m}^{2}$ & $C_{L}$ & $3.3 \times 10^{-4} \mathrm{~N} \cdot \mathrm{m} \cdot \mathrm{s} / \mathrm{rad}$ \\
\hline$K_{S}$ & $2.48 \mathrm{~N} \cdot \mathrm{m} / \mathrm{rad}$ & & \\
\hline
\end{tabular}

振および反共振角周波数はそれぞれ次式で与えられる。

$$
\omega_{n}=\sqrt{\left(\frac{1}{J_{M}}+\frac{1}{J_{L}}\right) K_{S}}, \quad \omega_{a}=\sqrt{\frac{K_{S}}{J_{L}}}
$$

(11) 式より，Fig. 1 の実験装置の物理パラメータを 周波数応答実験の結果に合うように決定した。結果を Table 2 に示す.

\section{2 正規化した物理モデル}

システムのできるだけ簡単な表現を導出する. システ ムの状態を $\bar{x}$

$$
\begin{aligned}
& \bar{x}=T x=\left[\begin{array}{c}
\alpha \omega_{M}+(1-\alpha) \omega_{L} \\
\theta_{r} \\
\omega_{L}-\omega_{M}
\end{array}\right]=\left[\begin{array}{c}
\omega_{\text {ave }} \\
\theta_{r} \\
-\dot{\theta}_{r}
\end{array}\right] \\
& T:=\left[\begin{array}{ccc}
0 & \alpha & 1-\alpha \\
1 & 0 & 0 \\
0 & -1 & 1
\end{array}\right], \quad \alpha:=\frac{1}{1+r}, \quad r:=\frac{J_{L}}{J_{M}}
\end{aligned}
$$

とおき, システムの入力を $\bar{u}:=\left[\frac{T_{L}}{J_{L}} \frac{T_{M}}{J_{M}}\right]^{\mathrm{T}}$ とする. さらに, $C_{L}$ は $P_{22}(s)$ の反共振のノッチの深さと低角周 波数域のゲインに変化を与えるのみで，本論文の主張に 影響を与えないため $C_{L}=0$ とすると， $\bar{u}$ から $y$ までの システム $\bar{P}$ の状態空間表現が次式で与えられる.

$$
\begin{gathered}
\dot{\bar{x}}=\bar{A} \bar{x}+\bar{B} \bar{u}, \quad y=\bar{C} \bar{x} \\
{\left[\begin{array}{c}
\bar{A}_{1}^{\prime} \bar{B} \\
\hdashline \bar{C}^{\prime} 0
\end{array}\right]=\left[\begin{array}{ccc:cc}
0 & 0 & 0 & 1-\alpha & \alpha \\
0 & 0 & -1 & 0 & 0 \\
0 & \omega_{n}^{2} & -2 \xi \omega_{n} & 1 & -1 \\
\hdashline 1 & 0 & \alpha & 0 & 0 \\
1 & 0 & \alpha-1 & 0 & 0
\end{array}\right],} \\
2 \xi \omega_{n}:=\left(\frac{1}{J_{M}}+\frac{1}{J_{L}}\right) C_{S}
\end{gathered}
$$

本論文では慣性比 $r$ が 10 以上の場合を扱う ${ }^{1}$. また，シ ステムの伝達関数行列は次式で与えられる.

\footnotetext{
${ }^{1} 10$ に特別な意味はなく, 6.2 で述べるように $r>6.49$ であれば提案型補償器とそのパラメー夕調整則が適用 できる。
} 


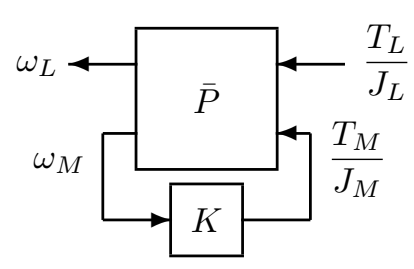

Fig. 8 Closed loop system

$$
\begin{aligned}
& \bar{P}(s):=\left[\begin{array}{cc}
\bar{P}_{11}(s) & \bar{P}_{12}(s) \\
\bar{P}_{21}(s) & \bar{P}_{22}(s)
\end{array}\right] \\
& =\frac{\left[\begin{array}{cc}
s^{2}+(1-\alpha)\left(2 \xi \omega_{n} s+\omega_{n}^{2}\right) & \alpha\left(2 \xi \omega_{n} s+\omega_{n}^{2}\right) \\
(1-\alpha)\left(2 \xi \omega_{n} s+\omega_{n}^{2}\right) & s^{2}+\alpha\left(2 \xi \omega_{n} s+\omega_{n}^{2}\right)
\end{array}\right]}{s\left(s^{2}+2 \xi \omega_{n} s+\omega_{n}^{2}\right)}
\end{aligned}
$$

このとき, $\omega_{n}$ と $\omega_{a}$ の関係は $\alpha$ を用いて次式のように 表せる.

$$
\omega_{a}=\omega_{n} \sqrt{\alpha}
$$

$\bar{P}$ と $K$ を用いると, Fig. 7 は Fig. 8 に示すような閉 ループ系となる。閉ループ伝達関数 $G_{\mathrm{cl}}$ は次式で与えら れる。

$$
\begin{aligned}
G_{\mathrm{cl}} & =\bar{P}_{11}+\frac{\bar{P}_{12} K \bar{P}_{21}}{1-\bar{P}_{22} K} \\
& =\frac{\bar{P}_{11}-\bar{P}_{11} K \bar{P}_{22}+\bar{P}_{12} K \bar{P}_{21}}{1-\bar{P}_{22} K}
\end{aligned}
$$

以降では簡単のため, $\omega_{n}=1$ の場合を考えるが, $\omega_{n} \neq 1$ の場合も同様に議論できる。

\section{5. 閉ループ系が安定となる条件}

本節では提案型補償器を用いた制御系が安定となるた めの, 可調整パラメータに関する条件を示す。ここから は，比例補償器を用いる場合についても述べる，PID 補 償器の微分動作は, 高周波数域で相補感度関数が小さく ならず，ロバスト安定性を損なうために省略する。また， 積分動作は 6.2 で $\mathcal{H}_{\infty}$ ノルム最小化に対して効果がな いことを示し，ここでも省略する。

\section{1 比例補償器の場合}

負実数 $K_{P}$ を用いて,

$$
T_{M}=K_{P} \omega_{M}
$$

とする比例制御系を考える。 $\bar{P}_{22}$ の位相遅れは $\pm 90^{\circ}$ に 収まることから，(負帰還とするためフィードバックの加 算点に -1 倍を導入したときの) 一巡伝達関数 $-\bar{P}_{22} K_{P}$ のベクトル軌跡は右半平面内に留まり，よって -1 を回 らず，閉ループ系は安定となる。よって， $K_{P}$ によらず， 位相余裕は $90^{\circ}$ 以上, ゲイン余裕は無限大となる.

\section{2 提案型補償器の場合}

閉ループ系が安定となるための条件をフルビッツの安 定判別により導出する。ただし，本論文ではねじり剛性
が低い制御対象を考えるため, 以降では簡単のため $\xi=0$ と仮定する。そのときの制御対象 $\tilde{P}(s)$ は以下となる.

$$
\left.\bar{P}(s)\right|_{\xi=0}=\tilde{P}(s)=\frac{\left[\begin{array}{cc}
s^{2}+(1-\alpha) & \alpha \\
1-\alpha & s^{2}+\alpha
\end{array}\right]}{s\left(s^{2}+1\right)}
$$

7.に示す実験では, $\xi \neq 0(\xi \ll 1)$ の装置を扱い, 提案 型補償器を使用できることを確認している.

次の結果が成り立つ.

【補題 1】閉ループ系が安定となるための必要十分条 件は次式が成り立つことである。

$$
\zeta>-a_{0} \frac{1-\alpha+a_{0} a_{1} \alpha-\sqrt{a_{0} a_{1} \alpha\left\{a_{0} a_{1} \alpha+2 \alpha(1-\alpha)\right\}}}{2\left(1+2 a_{0} a_{1} \alpha\right)}
$$

(証明)

$$
\begin{aligned}
& 1-\tilde{P}_{22}(s) K_{\text {prop }}(s) \\
= & 1+\frac{s^{2}+\alpha}{s\left(s^{2}+1\right)} a_{0} \frac{s^{2}+2 a_{1} s+1}{s^{2}+2 \zeta s+1}=0
\end{aligned}
$$

より，特性方程式は

$$
\begin{aligned}
& s^{5}+\left(2 \zeta+a_{0}\right) s^{4}+2\left(1+a_{0} a_{1}\right) s^{3} \\
& \quad+\left\{2 \zeta+a_{0}(1+\alpha)\right\} s^{2}+\left(1+2 a_{0} a_{1} \alpha\right) s+a_{0} \alpha=0
\end{aligned}
$$

となる. 特性多項式のすべての係数が正となるために， $a_{0}$ は

$$
\zeta>-\frac{a_{0}}{2}
$$

を満たすように選ばれる必要がある。行列 $H_{4}$ を

$$
H_{4}=\left[\begin{array}{cccc}
2 \zeta+a_{0} & 2 \zeta+a_{0}(1+\alpha) & a_{0} \alpha & 0 \\
1 & 2\left(1+a_{0} a_{1}\right) & 1+2 a_{0} a_{1} \alpha & 0 \\
0 & 2 \zeta+a_{0} & 2 \zeta+a_{0}(1+\alpha) & a_{0} \alpha \\
0 & 1 & 2\left(1+a_{0} a_{1}\right) & 1+2 a_{0} a_{1} \alpha
\end{array}\right]
$$

とおくとフルビッツの安定判別より， $\tilde{P}$ と $K_{\text {prop }}$ から 成る閉ループ系が安定となるための必要十分条件は,

$$
\left|H_{4}\right|>0, \quad\left|H_{2}\right|>0
$$

が成り立つことである。ただし， $H_{2}$ は $H_{4}$ の左上 2 行 2 列部分の行列である。

$$
\left|H_{2}\right|=2 a_{0}^{2} a_{1}+a_{0}\left(1-\alpha+4 a_{1} \zeta\right)+2 \zeta
$$

より, $\left|H_{2}\right|>0$ は次式と等価である.

$$
\zeta>-\frac{a_{0}}{2} \frac{1-\alpha+2 a_{0} a_{1}}{1+2 a_{0} a_{1}}
$$

また，

$$
\begin{aligned}
\left|H_{4}\right|=2 a_{0} a_{1}(1-\alpha)\{ & 8 a_{0} a_{1} \zeta^{2} \alpha+4 a_{0}^{2} a_{1} \zeta \alpha+4 \zeta^{2} \\
& \left.+4 a_{0} \zeta(1-\alpha)+a_{0}^{2}(1-\alpha)^{2}\right\}
\end{aligned}
$$


(30)

より，|$H_{4} \mid>0$ は (22) 式か次式が成り立つことと等価で ある。

$$
\zeta<-a_{0} \frac{1-\alpha+a_{0} a_{1} \alpha+\sqrt{a_{0} a_{1} \alpha\left\{a_{0} a_{1} \alpha+2 \alpha(1-\alpha)\right\}}}{2\left(1+2 a_{0} a_{1} \alpha\right)}
$$

ただし， $a_{0}>0 ， a_{1}>0, \alpha<1$ より $2 a_{0} a_{1}(1-\alpha)$ が正 であることを用いた（31) 式は (25) 式と (29) 式の条件 に矛盾する。一方で (22) 式が成り立つならば，(25) 式と (29) 式も成り立つ。したがって，閉ループ系が安定とな るための必要十分条件は $(22)$ 式が成り立つことである.

\section{6. 閉ループ系の $\mathcal{H}_{\infty}$ ノルムに関する制約 と提案型補償器による改善}

本節では，閉ループ系の $\mathcal{H}_{\infty}$ ノルムを最小化する補償 器を検討する。まず比例制御を用いる場合には，補償器 によらず閉ループ系のゲインが不変となる角周波数（ $\omega^{*}$ とする）が存在する制約があることを示し，比例制御系 の $\mathcal{H}_{\infty}$ ノルムの下限を与える。つぎに, 提案型補償器 の場合には，この制約が緩和され $\omega^{*} に$ に扮けるゲインを 比例制御系より小さくできることを示す，ただし， 5.2 と同様に制御対象 $\tilde{P}(s)$ について考える.

\section{1 比例補償器の場合}

閉ループ伝達関数は次式で与えられる。

$$
G_{\mathrm{cl}}=\tilde{P}_{11} \frac{1-c K_{P}}{1-\tilde{P}_{22} K_{P}}, \quad c:=\tilde{P}_{22}-\frac{\tilde{P}_{12} \tilde{P}_{21}}{\tilde{P}_{11}}
$$

このとき, $\omega_{a}=\sqrt{\alpha}$ より低い角周波数域において, $G_{\mathrm{cl}}$ と $\tilde{P}_{11}$ のゲインが一致する角周波数が存在する. 次の結 果が成り立つ。

【補題 2】閉ループ伝達関数 $G_{\mathrm{cl}}$ を(32) 式 で与え る.このとき，

$$
\omega^{*}=\sqrt{\frac{1-\sqrt{1-2 \alpha(1-\alpha)}}{2}}
$$

で与えられる角周波数 $\omega=\omega^{*}$ において次式が成り立つ.

$$
\left|G_{\mathrm{cl}}\left(j \omega^{*}\right)\right|=\left|\tilde{P}_{11}\left(j \omega^{*}\right)\right|=\frac{1-\alpha-\omega^{* 2}}{\omega^{*}\left(1-\omega^{* 2}\right)}
$$

（証明） (32)式の $c$ と $\tilde{P}_{22}$ が複素共役の関倸となる角 周波数が存在し，その角周波数に打ける閉ループ系のゲ インは, $\frac{1-c K_{P}}{1-\tilde{P}_{22} K_{P}}$ の絶対值が $K_{P}$ によらず 1 となる ことから，(34) 式のように $\tilde{P}_{11}$ のゲインで与えられる. $c$ と $\tilde{P}_{22}$ が複素共役の関係となることは, 次式と等価で ある。

$$
2 \tilde{P}_{11}(j \omega) \tilde{P}_{22}(j \omega)=\tilde{P}_{12}(j \omega) \tilde{P}_{21}(j \omega)
$$

ただし， $\overline{\tilde{P}_{22}(j \omega)}=-\tilde{P}_{22}(j \omega)$ を用いた。 (21) 式より，
上式を満たす解 $\omega=\omega^{*}$ が存在することは次のようにわか る: $\alpha \ll 1$ より角周波数带域 $\omega<\sqrt{\alpha}$ に打いて, $\tilde{P}_{11}(j \omega)$ と $\tilde{P}_{21}(j \omega)$ のゲインはほぼ等しい.ささらに, $2 \tilde{P}_{22}(j \omega)$ と $\tilde{P}_{12}(j \omega)$ のゲインは, 前者が低角周波数域で後者より も大きく, $\omega_{a}$ に近づくにつれて後者よりも小さくなる. よって, この角周波数帯域中に, 両者が一致する角周波 数が存在する. 実際, (35) 式を $\omega$ について解くと,

$$
\omega=\sqrt{\frac{1 \pm \sqrt{1-2 \alpha(1-\alpha)}}{2}}
$$

となり, $\omega<1$ より, 負号を選ぶと (33) 式を得る.

よって, 比例制御の場合, 補償器の選び方によらず閉 ループ系のゲインが不変となる角周波数が存在し，その 角周波数における開ループ系のゲインが比例制御系の $\mathcal{H}_{\infty}$ ノルムの下限を与える。実際には， $\left|K_{P}\right|$ を大きく すると $\omega^{*} よ り も$ 低周波数域のゲインは小さく，高周波 数域のゲインは大きくなり, 逆に $\left|K_{P}\right|$ を小さくすると 低周波数域のゲインは大きく，高周波数域のゲインは小 さくなり, 開ループ系のゲインに近づく。この中間に適 当な $\left|K_{P}\right|$ が存在し, (34) 式が比例制御系の $\mathcal{H}_{\infty}$ ノル ムの下限を与える。実際そのような $K_{P}$ は， $\omega^{*} に$ におけ る閉ループ系のゲイン (34) 式に次式で与えられる直流ゲ

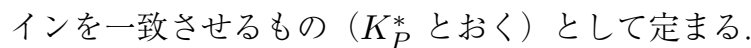

$$
G_{\mathrm{cl}}(0)=\left(\tilde{P} \star K_{P}\right)(0)=-\frac{1-\alpha}{\alpha K_{P}}
$$

すなわち，

$$
K_{P}^{*}=-\frac{(1-\alpha) \omega^{*}\left(1-\omega^{* 2}\right)}{\alpha\left(1-\alpha-\omega^{* 2}\right)}
$$

である。また， $\alpha \ll 1 よ り ~ \sqrt{1-2 \alpha(1-\alpha)} \simeq 1-\alpha$ と $(1-\alpha)\left(1-\omega^{* 2}\right) \simeq\left(1-\alpha-\omega^{* 2}\right)$ の近似を行うと,

$$
\omega^{*} \simeq \sqrt{\frac{\alpha}{2}}, \quad K_{P}^{*} \simeq-\frac{1}{\sqrt{2 \alpha}}
$$

を得る。

7.に示す実験では $\omega_{n}$ に制約がない一般の場合㧍よ

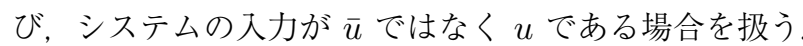
$\omega_{n} \neq 1$ においても $\omega_{n}=1$ のときと同様の手順を踏むこ とで, 次の結果が成り立つ $: \omega^{*}$ と $K_{P}^{*}$ の近似值は次式 で与えられる。

$$
\omega^{*} \simeq \sqrt{\frac{\alpha}{2}} \omega_{n}, \quad K_{P}^{*} \simeq-\frac{1}{\sqrt{2 \alpha}} \omega_{n}
$$

さらに，制御入力を $u$ とした場合に対する $K_{P}^{*}$ の近似 值は次式で与えられる.

$$
K_{P}^{*} \simeq-\frac{1}{\sqrt{2 \alpha}} \omega_{n} J_{M}
$$

制御入力 $u$ と $\bar{u}$ には $\bar{u}=\frac{u}{J_{M}}$ が成り立つことから, 制 御入力を $u$ とする補償器は制御入力を $\bar{u}$ とする補償器 
の $J_{M}$ 倍で与えられる.

\section{2 提案型補償器の場合}

(32) 式における $c$ と $\tilde{P}_{22}$ が複素共役となる角周波数 が存在する現象は, 制御対象固有のものである。よって, 比例補償器のようにこの角周波数における位相が $180^{\circ}$ である限り（または $0^{\circ}$ の場合も），この角周波数にお ける $\tilde{P}_{11}$ のゲインよりも小さな閉ループ系のゲインを得 ることはできない. 提案型補償器では, この角周波数付

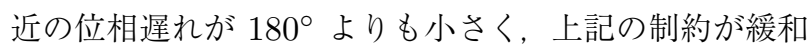
される。次の結果が成り立つ。

【補題 3】提案型補償器を用いたとき, 角周波数 $\omega^{*}$ における $\tilde{P}_{11}$ のゲインに対する閉ループ伝達関数 $G_{\mathrm{cl}}$ の ゲインの倍率 $\left|\frac{G_{\mathrm{cl}}\left(j \omega^{*}\right)}{\tilde{P}_{11}\left(j \omega^{*}\right)}\right|$ は 1 より小さい. すなわち, 次式が成り立つ。

$$
\left|\frac{1-c\left(j \omega^{*}\right) K_{\text {prop }}\left(j \omega^{*}\right)}{1-\tilde{P}_{22}\left(j \omega^{*}\right) K_{\text {prop }}\left(j \omega^{*}\right)}\right|<1
$$

（証明）提案型補償器の位相が

$$
-180^{\circ}<\angle K_{\text {prop }}(j \omega)<-90^{\circ} \quad\left(0<\omega<\omega_{a}\right)
$$

であることと, $\omega=\omega^{*}$ において $c$ が正の虚部をもつ純虚 数と見なせることから, $c\left(j \omega^{*}\right) K_{\text {prop }}\left(j \omega^{*}\right)$ は複素平面上 の第 4 象限 (実部が正, 虚部が負), $\tilde{P}_{22}\left(j \omega^{*}\right) K_{\text {prop }}\left(j \omega^{*}\right)$ は第 2 象限（実部が負，虚部が正）に入る。よって，(42) 式が成り立つ。

したがって, 角周波数 $\omega^{*}$ において比例補償器より 小さなゲインが達成される。ここで, 比例積分補償器 $K_{\mathrm{PI}}=K_{P}+\frac{K_{I}}{s}$ の場合には, フルビッツの安定判別よ り閉ループ系が安定となるための必要十分条件が $K_{P}$ と $K_{I}$ がともに負であること, これより

$$
90^{\circ}<\angle K_{\mathrm{PI}}(j \omega) \leq 180^{\circ}
$$

が成り立つことから，倍率 $\left|\frac{G_{\mathrm{cl}}\left(j \omega^{*}\right)}{\tilde{P}_{11}\left(j \omega^{*}\right)}\right|$ は 1 より大きく なる.よって, 積分動作は比例補償器で得られる性能を 改善しないため, 以降では比較対象として比例補償器の みを考える。

(42) 式の左辺を $\beta\left(a_{0}, a_{1}\right)$ とおき， $\omega=\omega^{*}$ における 比例補償器に対する改善率を指定することを考える。た だ，これを小さくしても $\omega=\omega^{*}$ 以外の周波数域で閉 ループゲインが上昇する可能性があるため, 特徽的な周 波数 $\left(\omega=0, \omega_{a}\right)$ より与えられる限界をまず考える. $\tilde{P}_{22}$ の反共振角周波数 $\omega_{a}$ における閉ループゲインの下限值 は，(25) 式より， $2 \zeta+a_{0}>0$ であることに注意すると，

$$
\begin{aligned}
& \left|G_{\mathrm{cl}}\left(j \omega_{a}\right)\right|=\left|\tilde{P}_{11}+\tilde{P}_{12} K_{\mathrm{prop}} \tilde{P}_{21}\right| \\
= & \frac{\sqrt{\alpha\left\{2 \zeta(1-2 \alpha)+a_{0}(1-\alpha)\right\}^{2}+\left\{1-\alpha(3-2 \alpha)-2 a_{0} a_{1} \alpha\right\}^{2}}}{\sqrt{\alpha}(1-\alpha) \sqrt{(1-\alpha)^{2}+4 \zeta^{2} \alpha}}
\end{aligned}
$$

$$
\geq \frac{2 \zeta(1-2 \alpha)+a_{0}(1-\alpha)}{(1-\alpha) \sqrt{(1-\alpha)^{2}+4 \zeta^{2} \alpha}}
$$

より， $a_{0}$ が小さいほど小さくなるが，逆に $\omega=0$ にお ける閉ループゲイン

$$
\left|G_{\mathrm{cl}}(j \cdot 0)\right|=\frac{1-\alpha}{\alpha a_{0}}
$$

は大きくなる。よって, (45) 式の下限值に $\left|G_{\mathrm{cl}}(j \cdot 0)\right|$ を 一致させる $a_{0}$ が

$$
a_{0}=\frac{1-2 \alpha}{1-\alpha}\left\{-\zeta+\sqrt{\zeta^{2}+\frac{(1-\alpha)^{3} \sqrt{(1-\alpha)^{2}+4 \zeta^{2} \alpha}}{\alpha(1-2 \alpha)^{2}}}\right\}
$$

と求まる。したがって, 比例制御の場合（(37) 式）との 比をとることで, $\beta\left(a_{0}, a_{1}\right)$ の下限が次のように定まる.

$$
\beta\left(a_{0}, a_{1}\right) \geq \frac{\frac{1-\alpha}{\alpha a_{0}}}{-\frac{1-\alpha}{\alpha K_{P}^{*}}}=\frac{-K_{P}^{*}}{a_{0}}>\frac{\sqrt{1-\alpha}}{\sqrt{\alpha}+\sqrt{2+\alpha}} \approx 0.71
$$

ただし，(33), (38) 式と $1-2 \alpha(1-\alpha)<\{1-\alpha(1-\alpha)\}^{2}$, $1-2 \alpha(1-\alpha)>(1-\alpha)^{2}$ の関係式より $-K_{P}^{*}$ の下限が

$$
-K_{P}^{*}=\frac{(1-\alpha) \omega^{*}\left(1-\omega^{* 2}\right)}{\alpha\left(1-\alpha-\omega^{* 2}\right)}>\sqrt{\frac{1-\alpha}{\alpha(2-\alpha)}}
$$

と表せることと，(47) 式と $(1-\alpha)^{2}+2 \alpha<(1+\alpha)^{2}$ ， $\frac{1-2 \alpha}{1-\alpha}<1, \quad 1-\alpha^{2}<1$ の関係式より $a_{0}$ の上限が

$$
a_{0}<\frac{1}{\sqrt{2}}+\sqrt{\frac{1}{2}+\frac{1}{\alpha}}
$$

と表せること，これらより次式が成り立つことを用いた

$$
\frac{-K_{P}^{*}}{a_{0}}>\sqrt{\frac{1-\alpha}{2-\alpha}} \frac{\sqrt{2}}{\sqrt{\alpha}+\sqrt{\alpha+2}}>\frac{\sqrt{1-\alpha}}{\sqrt{\alpha}+\sqrt{\alpha+2}} \approx \frac{1}{\sqrt{2}}
$$

よって, 比例制御系に対して, 閉ループ系の $\mathcal{H}_{\infty}$ ノル ムを改善するためには $0.71<\beta\left(a_{0}, a_{1}\right)<1$ である必要 がある。

$a_{0} ， a_{1}$ の設定法を考える. (48) 式を満たす $\beta$ が与え られたとする。これを $\beta^{*}$ とおき, 比例補償器のときと 同様に， $\omega=0 ， \omega^{*}$ における閉ループ系のゲインを一致 させる $a_{0}, a_{1}$ を $a_{0}^{*}, a_{1}^{*}$ とおけば，まず $a_{0}^{*}$ について次 式が成り立つ.

$$
a_{0}^{*}=\frac{1}{\beta^{*}}\left(-K_{P}^{*}\right)
$$

つぎに $\beta$ の式を変形し，二次方程式を解くことで $a_{1}^{*}$ を定めることを考える。すなわち $\omega^{*},\left(1-\frac{\alpha}{2}\right)^{2}, a_{0}$ を それぞれ $\sqrt{\frac{\alpha}{2}}, 1-\alpha,-K_{P}^{*}$ と置き換え, さらに $\alpha^{2}$ の 項を無視すると 


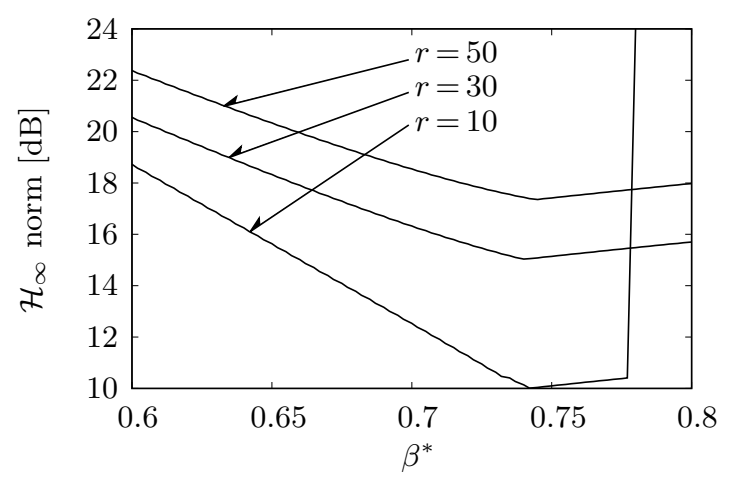

Fig. 9 Plot of $\mathcal{H}_{\infty}$ norm vs. $\beta^{*}$ with each $r$

$$
\beta^{*}=\sqrt{\frac{\frac{2(1-\alpha)}{\alpha}+4 \zeta^{2}-4\left(\zeta-a_{1}^{*}\right) K_{P}^{*}+K_{P}^{* 2}}{\frac{2(1-\alpha)}{\alpha}+4 \zeta^{2}+4\left(\zeta-a_{1}^{*}\right) K_{P}^{*}+K_{P}^{* 2}}}
$$

となる。この解は次式で与えられる.

$$
a_{1}^{*}=\zeta+\frac{5\left(1-\beta^{* 2}\right)}{4 \sqrt{2 \alpha}\left(1+\beta^{* 2}\right)}
$$

(49)，(51) 式によって与えられる $a_{0}^{*} ， a_{1}^{*}$ を用いて提 案型補償器を構成すると， $\omega=0, \omega^{*}$ における閉ループ ゲインは比例補償器を用いた閉ループ系のゲインのほぼ $\beta^{*}$ 倍となる。しかし, $\omega=0, \omega^{*}$ 以外の周波数におけ る閉ループゲインに保証はなく, 閉ループ系の $\mathcal{H}_{\infty}$ ) ルムがどう定まるかは明らかではない，そこで，各慣性 比 $r$ における $\beta^{*}$ に対する $\mathcal{H}_{\infty}$ ノルムの関係を数值的 に調べた結果を Fig. 9 に示す. $r$ によらず $\mathcal{H}_{\infty}$ ノルムが 最小となる $\beta^{*}$ がおよそ 0.74 であることがわかる。こ の理論的な根拠は明らかではないが, 経験的には Fig. 10 に示すように $\beta^{*}$ が小さい場合 $\left(\beta^{*}=0.64\right)$ は $\omega^{*}$ と共 振周波数の間の閉ループゲインが大きくなり, $\beta^{*}$ が大 きい場合 $\left(\beta^{*}=0.84\right)$ は補償器の直流ゲインが小さくな ることから低周波数域の閉ループゲインが大きくなるこ とがわかる。 よって以降では $\beta^{*}=0.74$ とする $a_{0}, a_{1}$ の設定法を提案する。なお， $r$ が大きいほど $\mathcal{H}_{\infty}$ ノル ムが増加する理由は, (39) 式より $r$ が増加 ( $\alpha$ が減少) すると $\omega^{*}$ が減少し, 開ループ系の積分特性により比例 制御系の $\mathcal{H}_{\infty}$ ノルムが増加することと, 提案型補償器 を用いた場合の $\omega=\omega^{*}$ における閉ループゲインが比例 制御の $\beta^{*}$ 倍で与えられることによる。 また，Fig.9の $r=10$ において $\beta^{*}=0.78$ 付近にある急激な立ち上がり は閉ループ系が不安定となることを表している。

$\beta^{*}$ によっては，(51) 式により定まる $a_{1}$ は負となり, 補題 1 の前提が成り立たない. よって, $a_{1}^{*}>0$ となる $\beta^{*}$ の範囲を求めると (51) 式より

$$
0<\beta^{*}<\sqrt{\frac{5-4 \sqrt{\alpha}}{5+4 \sqrt{\alpha}}}
$$

を得る. $r=10$ のとき, $(52)$ 式の右辺はおよそ 0.78 とな

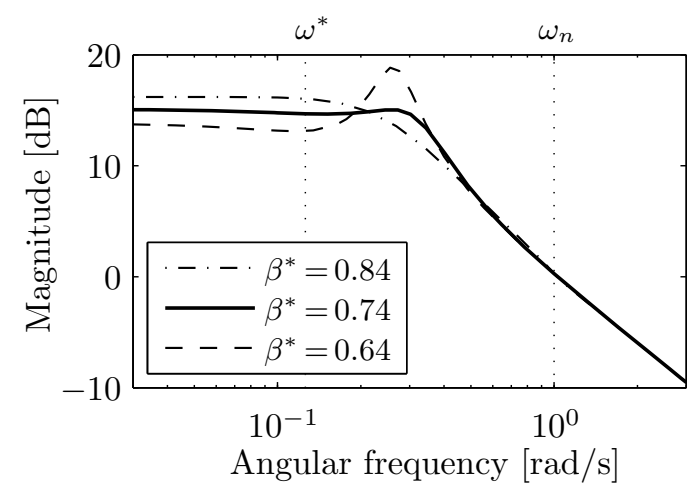

Fig. 10 Plot of closed loop gain by $\beta^{*}(r=30)$

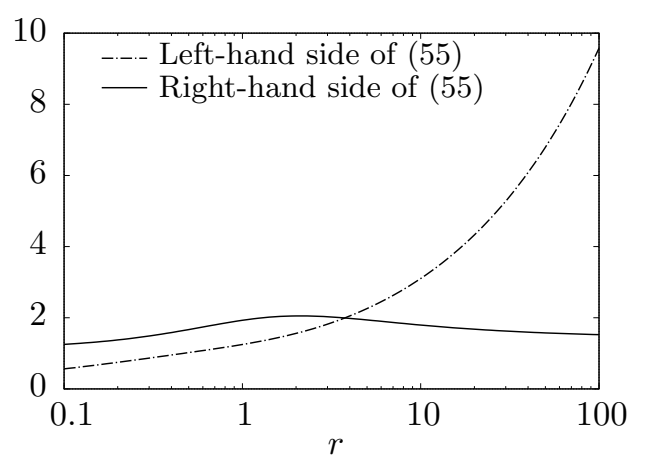

Fig. 11 Plot of left-hand side and right-hand side of (55) vs. $r\left(\beta^{*}=0.74\right)$

り, Fig. 9 の $r=10$ における急激な立ち上がりが生じる $\beta^{*}$ の值と一致する。前述のように本論文では $\beta^{*}=0.74$ とする $a_{0}, a_{1}$ の設定法を与えるため, (52) 式を満たす $r$ の範囲を求めると

$$
r>\left(\frac{4}{5} \cdot \frac{1+\beta^{* 2}}{1-\beta^{* 2}}\right)^{2}-1=6.49
$$

となる. よって本論文で考える $r \geq 10$ に対して $a_{1}^{*}>0$ が成り立つ。

最後に補題 1 を用いて閉ループ系が安定となる保証 を与える. $a_{0} a_{1} \alpha\left\{a_{0} a_{1} \alpha+2 \alpha(1-\alpha)\right\}<\left\{a_{0} a_{1} \alpha+\alpha(1-\right.$ $\alpha)\}^{2}$ より, (22) 式の十分条件が

$$
\zeta>-\frac{a_{0}}{2} \frac{(1-\alpha)^{2}}{1+2 a_{0} a_{1} \alpha}
$$

となる. 上式の $a_{1}$ に(51) 式の $a_{1}^{*}$ を代入すると，

$$
a_{0}>\frac{2 \sqrt{2}}{2(1-\alpha)^{2}-5 \sqrt{\alpha} \frac{1-\beta^{* 2}}{1+\beta^{* 2}}+4 \alpha}
$$

を得る. $r$ に対する (55) 式の左辺 $\left((49)\right.$ 式の $\left.a_{0}^{*}\right)$ と右 辺を Fig. 11 に示す. $r$ が大きくなるにつれて（すなわち $\alpha$ が 0 に近づくにつれて) (38) 式より $a_{0}^{*}$ は一様に増加 し，(55) 式右辺は $\sqrt{2}$ に漸近する.おおよそ $r>4$ のと きに $(55)$ 式を満たすことがわかる. したがって, 高慣性 比 $(r \geq 10)$ の場合は (53), (55) 式が成り立ち閉ループ系 は安定となる. 
Table 3 Parameter of controller

\begin{tabular}{c|c}
\hline Controller & Parameter \\
\hline \hline Proposed & $\beta^{*}=0.74, a_{0}^{*}=0.0257, a_{1}^{*}=0.244$ \\
\hline Proportional & $K_{P}^{*}=-0.0190$ \\
\hline $\mathcal{H}_{\infty}$ & - \\
\hline $\mathrm{PD}$ & $K_{P}=0.0227, T_{D}=10^{-2.43}=0.00372$ \\
\hline
\end{tabular}

Table 4 Stable margin and $\gamma$

\begin{tabular}{c|c|c|c}
\hline Controller & Gain margin & Phase margin & $\gamma$ \\
\hline \hline Proposed & $6.46 \mathrm{~dB}$ & $37.5^{\circ}$ & $31.8 \mathrm{~dB}$ \\
\hline Proportional & $\infty$ & $90.2^{\circ}$ & $34.5 \mathrm{~dB}$ \\
\hline $\mathcal{H}_{\infty}$ & $5.21 \mathrm{~dB}$ & $40.0^{\circ}$ & $31.6 \mathrm{~dB}$ \\
\hline PD & $\infty$ & $61.7^{\circ}$ & $32.8 \mathrm{~dB}$ \\
\hline
\end{tabular}

以上より, $a_{0} ， a_{1}$ の設定法を次のように提案する

(1) $\beta^{*}=0.74$ とする.

(2) (39), (49), (51) 式より $a_{0}^{*} ， a_{1}^{*}$ を求める.

(3) $a_{0}=a_{0}^{*} ， a_{1}=a_{1}^{*}$ と設定した次式を提案する補償 器とする。

$$
K_{\text {prop }}^{*}=-a_{0}^{*} \frac{s^{2}+2 a_{1}^{*} \omega_{n} s+\omega_{n}^{2}}{s^{2}+2 \zeta \omega_{n} s+\omega_{n}^{2}}, \quad \zeta=-\frac{1}{\sqrt{2}}
$$

7.に示す実験では $\omega_{n}$ に制約がない一般の場合およ び, システムの入力が $\bar{u}$ ではなく $u$ である場合を扱う. 比例制御の場合と同様に, $\omega_{n} \neq 1$ に対する $K_{\text {prop }}^{*}$ は $\omega_{n}$ 倍で与えられる.さらに, $u$ に対する $K_{\mathrm{prop}}^{*}$ においても $\omega_{n} J_{M}$ 倍で与えられる。

\section{7. 実験による検証}

(11) 式の $P$ に対して提案型・比例 $\cdot \mathcal{H}_{\infty} \cdot \mathrm{PD}$ 補償 器を適用した際の性能を比較する。物理パラメー夕は Table 2 を使い, 比例補償器は (41) 式を, 提案型補償器 には前節の設定法を使用した。 $\mathcal{H}_{\infty}$ 補償器は 3.1 と同じ 補償器である. $\mathrm{PD}$ 補償器 $K_{\mathrm{PD}}=-K_{P}\left(1+T_{D} s\right)$ の調 整は， $K_{P}$ を 0.015 から 0.030 まで 0.0001 刻み, $T_{D}$ を 常用対数の指数の -3 から -2 まで 0.01 刻みでメッシュ 探索して行った ${ }^{1}$. 各補償器のパラメータをTable 3 に 示す.

閉ループ系のゲイン特性の計算結果を Fig. 12 に，ゲ イン余裕，位相余裕および $\gamma$ を Table 4 に示す. $\omega^{*}=$ $67.2 \mathrm{rad} / \mathrm{s}$ であり, それよりも低角周波数域でほぼ ラットなゲインが得られている。結果として提案型補償 器は比例補償器と比べて $\gamma$ を $2.7 \mathrm{~dB}$ 下げることがで き，この下がり幅は $\frac{1}{\beta^{*}} \approx 2.6 \mathrm{~dB}$ とほぼ一致する。ま た, $\mathcal{H}_{\infty}$ 補償器とほぼ同等の $\gamma$ を実現した。 PD 補償器 の場合も $\omega^{*}$ における位相が進むことで性能が改善され るが, 比例補償器に対する $\gamma$ の改善幅は $1.7 \mathrm{~dB}$ にとど まる。

Fig. 12 の妥当性を確認するために実験を行った，実験

この範囲は $\gamma$ に関する極小点が含まれることを数值的 に確認して決定した。

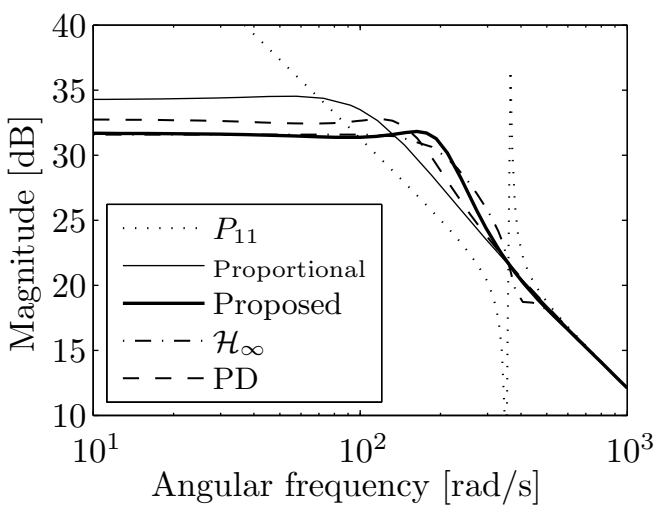

Fig. 12 Numerical examples of closed loop gain
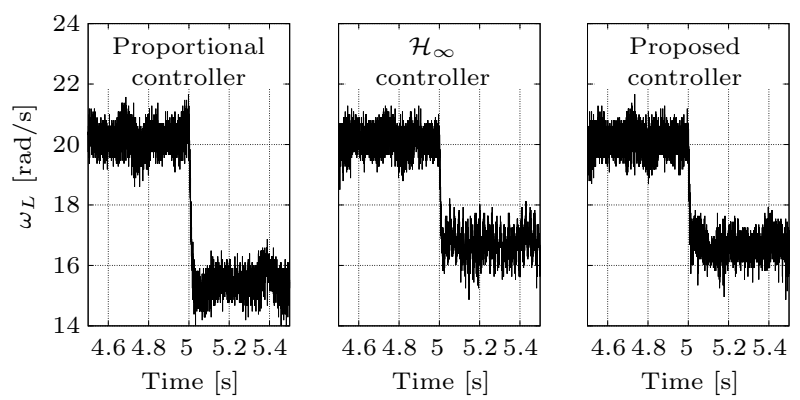

Fig. 13 Experimental result with step disturbance

装置の概要と諸元はそれぞれ Fig. 1 と Table 1 である. 参照角速度を $20 \mathrm{rad} / \mathrm{s}$ として速度制御を行い，駆動中 に外乱トルクを加えて, 従動側角速度 $\omega_{L}$ の時間応答を 計測した。 まず，ステップ外乱を加えたときの $\omega_{L}$ の時 間応答を Fig. 13 に示す. $5 \mathrm{~s}$ のときに外乱が加えられ， $\omega_{L}$ が $\mathcal{H}_{\infty}$ 補償器・提案型補償器で約 $3 \mathrm{rad} / \mathrm{s}$ だけ, 比 例補償器で約 $4.5 \mathrm{rad} / \mathrm{s}$ だけ落ち込んでいる。この落ち 込みの幅を比べると約 $3 \mathrm{~dB}$ であり, Fig. 12 の数值例と おおむね一致する。つぎに, $10 \mathrm{~Hz}(62.8 \mathrm{rad} / \mathrm{s})$ の正弦 波外乱を加えたときの $\omega_{L}$ の時間応答を Fig. 14 に示す. ステップ外乱のときと同様に, 比例補償器よりも $\mathcal{H}_{\infty}$ 補 償器・提案型補償器の方が $\omega_{L}$ の振幅の大きさを約 $3 \mathrm{~dB}$ 抑えられており, Fig. 12 の数值例とおおむね一致する. 最後に, $30 \mathrm{~Hz}(188 \mathrm{rad} / \mathrm{s})$ の正弦波外乱を加えたとき の $\omega_{L}$ の時間応答を Fig. 15 に示す。このときは, $\mathcal{H}_{\infty}$ 補償器 - 提案型補償器よりも比例補償器の方が $\omega_{L}$ の振 幅の大きさを若干抑えられており, Fig. 12 の数值例と定 性的に一致する，定量的な比較を行うため $\omega_{L}$ の時間応 答から $L_{2}$ ノルムを算出した結果を Table 5 に示す. 4 列目は閉ループゲインに対応しており，Fig. 12 とおおむ ね整合する結果であることがわかる，数值例と実験結果 の良好な一致が確認でき, 提案型補償器とその調整法の 実用性を示した。 なお, 周波数重みを導入して低周波 数域の外乱抑制性能を重視する場合などの検討は今後の 課題としたい. 


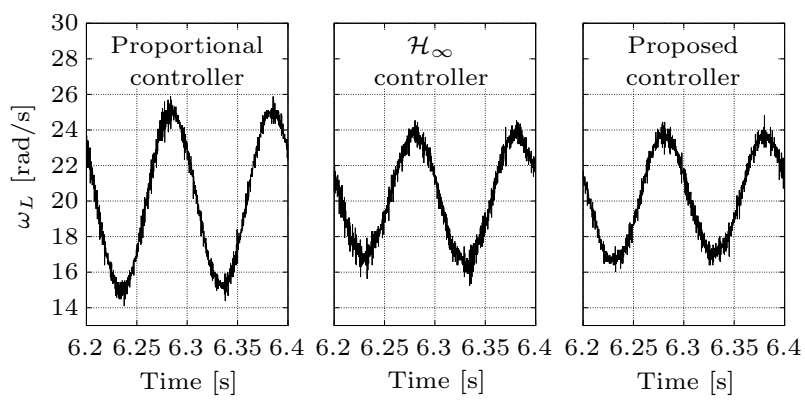

Fig. 14 Experimental result with disturbance of $10 \mathrm{~Hz}$ $(62.8 \mathrm{rad} / \mathrm{s})$

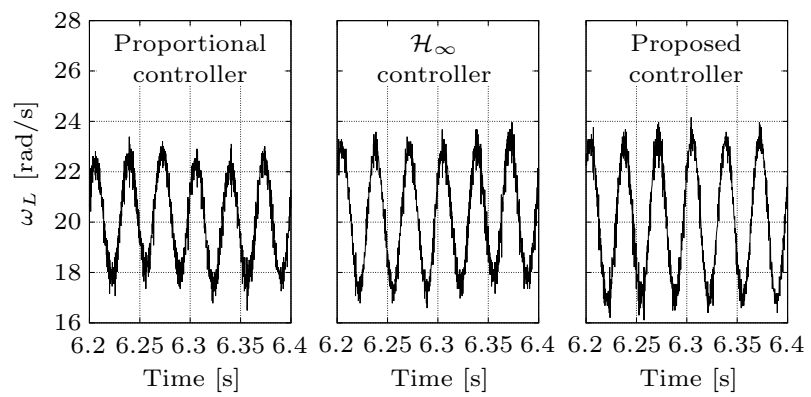

Fig. 15 Experimental result with disturbance of $30 \mathrm{~Hz}$ $(188 \mathrm{rad} / \mathrm{s})$

Table $5 \quad L_{2}$ norm of experimental results

\begin{tabular}{c|c|c|c}
\hline Disturbance & Controller & $\left\|\omega_{L}-20\right\|_{2}$ & $20 \log _{10} \frac{\left\|\omega_{L}-20\right\|_{2}}{\left\|T_{L}\right\|_{2}}$ \\
\hline \hline \multirow{2}{*}{$\begin{array}{c}\text { Step } \\
0 \mathrm{~Hz}\end{array}$} & Proportional & 379 & $33.5 \mathrm{~dB}$ \\
\cline { 2 - 4 }$(0 \mathrm{rad} / \mathrm{s})$ & $\mathcal{H}_{\infty}$ & 278 & $30.8 \mathrm{~dB}$ \\
\cline { 2 - 4 } & Proposed & 283 & $31.0 \mathrm{~dB}$ \\
\hline \multirow{3}{*}{$\begin{array}{c}10 \mathrm{~Hz} \\
(62.8 \mathrm{rad} / \mathrm{s})\end{array}$} & Proportional & 297 & $34.4 \mathrm{~dB}$ \\
\cline { 2 - 4 } & $\mathcal{H}_{\infty}$ & 216 & $31.7 \mathrm{~dB}$ \\
\hline \multirow{3}{3}{$\begin{array}{c}30 \mathrm{~Hz} \\
(188 \mathrm{rad} / \mathrm{s})\end{array}$} & Proposed & 208 & $31.3 \mathrm{~dB}$ \\
\cline { 2 - 4 } & $\mathcal{H}_{\infty}$ & 142 & $28.0 \mathrm{~dB}$ \\
\cline { 2 - 4 } & Proposed & 189 & $29.5 \mathrm{~dB}$ \\
\hline
\end{tabular}

\section{8. おわりに}

低剛性・高慣性比の二慣性系の制御対象において, 安 定な補償器で得られる制御性能を改善するために, $\mathcal{H}_{\infty}$ 制御系設計で得られる不安定な補償器の特徵を持ち，か つ物理パラメータが変動した際の補償器の再設計が不要 で定数ゲインと不安定なノッチフィルタの深さに関する 二つの可調整パラメータを有する 2 次の補償器を提案し た。適当な安定余裕を確保し，かつ閉ループ系のゲイン を最小化するような可調整パラメータの設定法を示した. 提案型補償器の実用性を実験により確認した。

今後は, $\beta^{*}=0.74$ となる理論的根拠を解析するとと もに, 提案型補償器のパラメータ $\zeta$ を可変とすること で，ユーザが指定した性能を達成する補償器パラメータ の導出を目指す.

\section{謝 辞}

本研究を進めるにあたり貴重なご助言・ご支援をいた だた元長岡技術科学大学助教授 羅正華先生に深く感謝
いたします。

\section{参 考文 献}

[1] 株式会社安川電機: $\Sigma-V$ シリーズ総合カタログ資料 番号 KAJP S800000 42S

[2] オリエンタルモーター株式会社: チューニングレス $\mathrm{AC}$ サーボユニット NX シリーズ ユーザーズマニュアル

[3] 松井, 堀: モータコントロールの新しい技術; 電気学会 論文誌 D, Vol. 113，No. 10, pp. 1122-1137 (1993)

[4] 森本, 亀山, 武田: 2 慣性系の速度制御における共振比制 御と $\mathcal{H}_{\infty}$ 制御の特性比較; 電気学会論文誌 D, Vol. 116, No. 6, pp. 678-684 (1996)

[5] 松井: PID 制御による 2 慣性系の速度制御; 電気学会論 文誌 D, Vol. 116, No. 4, pp. 441-447 (1996)

[6] G. Zhang and J. Furusho: Speed control of twoinertia system by PI/PID control; IEEE Trans. Ind. Electron., Vol. 47, No. 3, pp. 603-609 (2000)

[7] K. Szabat and T. Orlowska-Kowalska: Vibration suppression in a two-mass drive system using PI speed controller and additional feedbackscomparative study; IEEE Trans. Ind. Electron., Vol. 54, No. 2, pp. 1193-1206 (2007)

[8] R. Muszynski and J. Deskur: Damping of torsional vibrations in high-dynamic industrial drives; IEEE Trans. Ind. Electron., Vol. 57, No. 2, pp. 544-552 (2010)

[9] 西村, 小林, 五井: 物理パラメー夕に陽に依存する補償 器を用いたベルト駆動二慣性系の外乱抑制制御; 第 56 回 自動制御連合講演会, pp. 740-743（2013）

[10] 大内, 美多, 矢野: $\mathcal{H}_{\infty}$ 制御理論に基づく電動機の制振 制御; 電気学会論文誌D, Vol. 113, No. 3, pp. 325-332 (1993)

[11] 森本, 武田: $\mathcal{H}_{\infty}$ 制御制御理論を用いた共振機械系の 2 自由度速度制御; 電気学会論文誌 D, Vol. 116, No. 1, pp. 65-70 (1996)

\section{著者略歴}
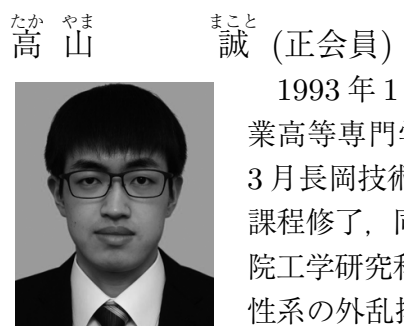

1993 年 1 月 3 日生. 2013 年 3 月群馬工 業高等専門学校機械工学科卒業，2015 年 3 月長岡技術科学大学工学部機械創造工学 課程修了, 同年 4 月長岡技術科学大学大学 院工学研究科機械創造工学専攻入学. 二慣 性系の外乱抑制制御の研究に従事.

示林 泰秀 (正会員)

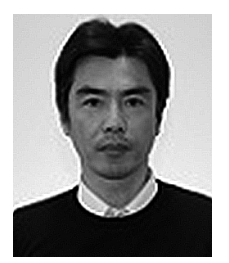

1995 年東京工業大学大学院理工学研究 科制御工学専攻修士課程修了。同年長岡技 術科学大学助手. 2002 年博士 (工学) 取 得 (東京工業大学)。2007 年同准教授とな り現在に至る。実システムのロバスト制御 に関する研究に従事. 計測自動制御学会, 日本機械学会, 日本音響学会の会員. 